\title{
Studies on Inter- generic Grafting Compatibility of Ornamental Cacti
}

\author{
R. Perumal, M. Prabhu* , M. Kannan and S. Srinivasan \\ Horticultural College and Research Institute, Tamil Nadu Agricultural University, \\ Coimbatore, India \\ *Corresponding author
}

\section{A B S T R A C T}

\section{Keywords}

Cacti,

Compatibility,

Grafting,

Intergeneric,

Ornamental

\section{Article Info}

Accepted:

15 October 2020

Available Online:

10 November 2020
In cacti, grafting has become a commercial method of propagation to accelerate and hasten the growth rate of slow growing species, to ensure the survival of the plants with poor root system, to ensure the survival of genetic aberration of variegated and brightly coloured cacti that lack chlorophyll, to accelerate the growth of plants for commercial use. With the above futuristic background, the present study on ornamental cacti grafting with all possible combinations of two species of rootstocks (Hylocereus triangularis and Myrtillocactus geometrizans) and five species of scions (Mammillaria beneckei, Hamatocactus setispinu, Ferocactus latispinus, Echinopsis mamillosa and Gymnocalycium mihanovichii) was carried out during 2017-18 at the Horticultural College and Research Institute, Tamil Nadu Agricultural University, Coimbatore, Tamil Nadu, India to assess the compatibility of grafted ornamental cacti and its performance. Among the graft combinations, the success and survival percentage were found to be maximum in graft with Hylocereus triangularis as stock and Echinopsis mamillosa as scion $(90 \%$ and $100 \%$ ) whereas it was maximum with Myrtillocactus geometrizans as stock and Hamatocactus setispinus as scion (96\% and 100\%). The results of grafting studies indicated that the compatibility was found to be good when scions like Mammillaria beneckei and Echinopsis mamillosa are grafted onto Hylocereus triangularis whereas Hamatocactus setispinus and Mammillaria beneckei are suitable scions when Myrtillocactus geometrizans is used as rootstock.

\section{Introduction}

Ornamental horticulture has attained importance to maintain the natural environment which had been deteriorated due to rapid urbanization during the past few decades. India is bestowed with several agroclimatic zones conducive for production of sensitive and delicate floricultural products. Among the floricultural produces, Cacti, a xerophytic plant, have a peculiar beauty and attraction for their strange morphological characteristics for which it is widely used in landscaping. The infinite, unique variations in shape, size, colour of areoles and spines make the plants look more curious and interesting (Shewell-Cooper and Rochford, 1973).

Nowadays, cacti and succulents can be utilized in large-scale in landscaping industry. 
These plants suit very effectively for both indoor and outdoor decorations. Rock garden is an interesting feature in any type of garden. The appealing and captivating form of cacti, make them a potential element in the field of landscaping. Despite their attractiveness, the hardness and the survival capacity of the cacti, make them an integral part in landscaping features viz., rockery, xeriscaping etc.

Cacti can be propagated by seeds, cuttings and offsets or grafting. Some species of Ferocactus, Mammillaria, Melocactus are self-fertile and hence they form seeds whereas species of Astrophytum and Gymnocalycium are self-sterile and hence require artificial cross pollination to achieve seed development. The case of vegetative propagation is due to the prevailing constraints viz., slow growing nature and selfsterility etc. (Bewli, 2016). Grafting, being an efficient mode of perpetuation of planting materials in their true-to-type nature, offers many genera of cacti, a way of survival. It has been noted that, the ordinary mode of multiplication viz., cuttings, layerings, offshoots etc., are not found to be economical and feasible for large scale production of cacti like Gymnocalycium mihanovichii, owing to its achlorophyllous nature. Grafted cacti are now regarded as one of the most admired ornamental indoor plants in worldwide. In cacti, grafting has become a commercial method of propagation to accelerate and hasten the growth rate of slow growing species, to ensure the survival of the plants with poor root system, to ensure the survival of genetic aberration of variegated and brightly coloured cacti (red and yellow caps) that lack chlorophyll, to accelerate the growth of plants for commercial use, in order to keep cristate and monstrose forms look attractive (Motlaghzadeh, 2007), to provide a handy tool in the hands of conservationists to save endangered species and to attain some unusual distinct growth forms that get developed on graft. Owing to the prevalence of un-preferable morphological modifications in majority of the cacti genera, they are generally hard to be preferred as garden plant or for interiorscaping. But, with the aid of grafting technology, species which are attractive and thorny such as Gymnocalycium sp. and Mammillaria sp. can be grafted onto thorny or hardy rootstocks such as Hylocereus sp., Myrtillocactus sp. etc., which helps to make an excellent indoor plant (Perumal et al., 2018). With the above futuristic background, the present study on ornamental cacti grafting was carried out to assess the compatibility of grafted ornamental cacti and its performance

\section{Materials and Methods}

The experiments were conducted in the Glass house, Botanical garden, Horticultural College and Research Institute, Tamil Nadu Agricultural University, Coimbatore. Different genera of cacti were collected from the Regional Plant Resource Centre (RPRC), Bhubaneswar, Odisha. The description of different genera of ornamental cacti (Family: Cactaceae and Tribe: Cereeae) used in this study is given below (Table 1).

The experiment was laid out by Factorial Completely Randomized Block Design (FCRBD) with ten treatments, each treatment was replicated thrice and each replication with three plants and details are given below.

\section{Factor I Rootstocks (2 levels)}

$\mathrm{R}_{1}$ : Hylocereus triangularis

$\mathrm{R}_{2}$ : Myrtillocactus geometrizans

Factor II Scions (5 levels)

$\mathrm{S}_{1}$ : Mammillaria beneckei

$\mathrm{S}_{2}$ : Hamatocactus setispinus 
$\mathrm{S}_{3}:$ Ferocactus latispinus

$\mathrm{S}_{4}$ : Echinopsis mamillosa

$\mathrm{S}_{5:}$ Gymnocalycium mihanovichii

One year old plant of the cacti genera was used as rootstocks. Healthy cacti plants were selected as scion materials. Care was taken while selecting the scion material to match the girth of the rootstock. Flat grafting was followed and this method, a horizontal cut is made on both the stock and scion; and they should be more or less of the same width at the graft union. The scion is kept fixed on the stock by giving a moderate pressure by tying the scion with the potted stock. In order to achieve maximum graft success and growth, the grafted plants were irrigated at weekly intervals based on the prevailing micro climatic conditions inside the growing structure. For ensuring the compactness between the rootstock and scion after grafting, the rubber bands used to tie the grafts together. After 3-4 days from grafting, the bands were removed in order to avoid constricted growth. The rootstock sprouts were removed at periodical intervals to ensure nutrient supply to the scions from the stock. The plants were provided with soil drenching of $0.5 \%(19: 19: 19)$ at fortnight intervals to assist the plant's growth. The graft success percentage was calculated 30 days after grafting and survival percentage was calculated 90 days after grafting. The height and girth of the grafted scion was measured from the graft union on the rootstock to the tip of the scion at monthly intervals. The flowering behaviour and offshoots production of the grafted cacti involved in the present study has been recorded. In order to study the ultra-structural change in the inter-generic grafting of selected cacti, microtome study was taken up and anatomical observations were carried out under microscope following the method suggested by Johanson, 1940. The results of the experiment were statistically analyzed by SPSS (Nei, 1978).

\section{Results and Discussion}

The success of grafting depends on the compatibility between the rootstock and scion. A successful graft is based on vascular reconnection. The variation in grafting success suggests that the change in amount and time taken for callus formation and also the use of rootstock profoundly influence the rate of success. Success and survival percentage of the inter-generic grafts were found to be varying significantly among the rootstocks and scions. Among the grafted plants, the success percentage was found to be maximum in graft with $\mathrm{R}_{1}$ (Hylocereus triangularis) as stock and $\mathrm{S}_{4}$ (Echinopsis mamillosa) as scion whereas it was maximum with $\mathrm{R}_{2}$ (Myrtillocactus geometrizans) as stock and $\mathrm{S}_{2}$ (Hamatocactus setispinus) as scion. Other reports with in vitro grafting studies of Opuntia ficusindica and Pelecyphora aselliformis as stock and scion respectively, has revealed that the success percentage was about 97 percentage when apical portion of the scion was used as scion (Badalamenti, et al., 2016). The higher percentage of survival may be due to active growth of meristematic tissues of both the rootstock and the scion, which facilitates callus formation thereby enhancing the grafting success.

Among the scions used for grafting, Ferocactus latispinus has recorded the lowest success percentage owing to its lignified stems. This poor success percentage may be associated with partial or total detachment of the scion after grafting, lignification of the stems. In certain grafts with the same scion, stunted growth was observed which may be due to the partially incompatible stock scion relationship. Some of these causes might be insufficient growth of the callus, formation of necrotic zone at the graft union, defects in phloem differentiation, etc. The reduced success percentage in few grafts may be 
associated with the misplacement of scion over the stock i.e., the vascular bundles of the graft portions may not be in good contact. It has been reported that there is slight reorientation in new vascular connections which may be the result of uneven match of the stock and scion at the graft union (Esau, 1965). In regard of survival percentage, the grafts with $\mathrm{R}_{1}$ (Hylocereus triangularis) as stock and $\mathrm{S}_{4}$ (Echinopsis mamillosa) as scion and it was maximum in grafts with $\mathrm{R} 2$ (Myrtillocactus geometrizans) as stock and $\mathrm{S}_{2}$ (Hamatocactus setispinus) as scion.

The higher success and survival rates of certain rootstock-scion combinations observed in the present study may be attributed to higher compatibility between the rootstock and scion (Table 2).

It may be associated with the strong callus bridge formation between rootstock and scion and differentiation of newly developed callus cells into vascular bundles (Estrada-Luna et al., 2002). Grafted scion height and girth are indications of plant vigour. The increased vigour in grafted plants might be due to early callusing at the graft joint as a result of early supply of food materials. Grafted scion height found to be increasing in due course and significant differences was found among the inter-generic grafts While $\mathrm{R}_{1}$ (Hylocereus triangularis) was used as the rootstock, the scion height was found to be maximum in $S_{2}$ (Hamatocactus setispinus) wherein $\mathrm{R}_{2}$ (Myrtillocactus geometrizans) as rootstock has been found to increase the height of $\mathrm{S}_{2}$ (Hamatocactus setispinus) comparatively compared to others. Grafted scion girth is an important morphological parameter that influences the visual appeal of the cacti graft. It was found to be maximum in grafts with $\mathrm{R}_{1}$ (Hylocereus triangularis) and $\mathrm{S}_{2}$ (Hamatocactus setispinus) and $\mathrm{R}_{2}$ (Myrtillocactus geometrizans) and $\mathrm{S}_{2}$ (Hamatocactus setispinus) as rootstocks and scions respectively, in both the cases (Table 2).

This might be due to the steady supply of food materials from the stock to the scion without interruption coupled with favourable climatic conditions for their growth. The growth of callus is an important physiological process in the development of the graft union, which in turn results in the increased scion height and girth.

Among the various grafted cacti, the grafts with $\mathrm{R}_{1}$ (Hylocereus triangularis) as rootstock and $\mathrm{S}_{5}$ (Gymnocalycium mihanovichii) as scion, $\mathrm{R}_{2}$ (Myrtillocactus geometrizans) as rootstock and $\mathrm{S}_{1}$ (Mammillaria beneckei) as scion and $\mathrm{R}_{2}$ (Myrtillocactus geometrizans) as rootstock and $\mathrm{S}_{5}$ (Gymnocalycium mihanovichii) as scion have produced flowers during the experimental period. The observations during the experimental period revealed that among the intergeneric grafts, the grafts with $\mathrm{R}_{1}$ (Hylocereus triangularis) as rootstock and $\mathrm{S}_{4}$ (Echinopsis mamillosa) as scion, $\mathrm{R}_{2}$ (Myrtillocactus geometrizans) as rootstock and $\mathrm{S}_{4}$ (Echinopsis mamillosa) as scion and $\mathrm{R}_{2}$ (Myrtillocactus geometrizans) as rootstock and $\mathrm{S}_{5}$ (Gymnocalycium mihanovichii) have the capacity to produce offshoots (Table 3).

Histological observations of the grafted plants give a picturesque effect of the graft compatibility of the grafts at anatomical level. It clearly emphasizes the status of the graft compatibility by exposing the nature of vascular connectivity and callus formation between the scion and the stock. In the present study, the microtome image of the inter-generic grafts clearly reveals the development of callus cells, differentiation of the callus cells to regenerate permanent tissues i.e., vascular bundles (vasculature) and developed vascular bundles which ensures the graft success. 
Table.1 Brief taxonomy description of ornamental cacti used in the present study

\begin{tabular}{|c|l|l|l|}
\hline Sl. No. & Common name & Botanical name & Origin \\
\hline $\mathbf{1}$ & Night blooming cactus & Hylocereus triangularis & West Indies \\
\hline $\mathbf{2}$ & Blue candle cactus & Myrtillocactus geometrizans & Mexico \\
\hline $\mathbf{3}$ & Pin Cushion Cactus & Mammillaria beneckei & North America \\
\hline $\mathbf{4}$ & Strawberry cactus & Hamatocactus setispinus & Mexico and Texas \\
\hline $\mathbf{5}$ & Barrel Cactus & Ferocactus latispinus & Mexico \\
\hline $\mathbf{6}$ & Turk's cap cactus & Melocactus caesius & $\begin{array}{l}\text { Venezuela and } \\
\text { Columbia }\end{array}$ \\
\hline $\mathbf{7}$ & Chin Cactus & Gymnocalycium mihanovichii & Argentina and Bolivia \\
\hline $\mathbf{8}$ & Easter Lily Cactus & Echinopsis mamillosa & South America \\
\hline
\end{tabular}

Table.2 Effect of inter-generic graft combinations on success and survival percentage, graft height and girth

\begin{tabular}{|c|c|c|c|c|c|c|c|c|c|c|c|c|}
\hline \multirow[t]{2}{*}{ Combinations } & \multicolumn{3}{|c|}{$\begin{array}{l}\text { Graft success } \\
\text { percentage }\end{array}$} & \multicolumn{3}{|c|}{$\begin{array}{l}\text { Graft survival } \\
\text { percentage }\end{array}$} & \multicolumn{3}{|c|}{ Graft height (cm) } & \multicolumn{3}{|c|}{ Graft girth (cm) } \\
\hline & $\mathrm{R}_{1}$ & & $R_{2}$ & $\mathrm{R}_{1}$ & & $R_{2}$ & $\mathrm{R}_{1}$ & & $R_{2}$ & \multicolumn{2}{|c|}{$\mathrm{R}_{1}$} & $\mathrm{R}_{2}$ \\
\hline $\begin{array}{l}\text { Mammillaria } \\
\text { beneckei }\left(\mathrm{S}_{1}\right)\end{array}$ & 83 & & 35 & 90 & & 5 & 3.29 & & .11 & \multicolumn{2}{|c|}{9.58} & 17.06 \\
\hline $\begin{array}{l}\text { Hamatocactus } \\
\text { setispinus }\left(\mathbf{S}_{2}\right)\end{array}$ & 70 & & 96 & 85 & & 00 & 5.51 & & 85 & \multicolumn{2}{|c|}{17.45} & 18.49 \\
\hline $\begin{array}{l}\text { Ferocactus } \\
\text { latispinus }\left(\mathrm{S}_{3}\right)\end{array}$ & 50 & & 30 & 80 & & 39 & 4.63 & & 96 & \multicolumn{2}{|c|}{14.27} & 15.86 \\
\hline $\begin{array}{l}\text { Echinopsis } \\
\text { mamillosa }\left(\mathbf{S}_{4}\right)\end{array}$ & 90 & & 35 & 100 & & 8 & 3.59 & & 65 & \multicolumn{2}{|c|}{10.24} & 10.23 \\
\hline $\begin{array}{l}\text { Gymnocalycium } \\
\text { mihanovichii }\left(\mathrm{S}_{5}\right)\end{array}$ & 80 & & 90 & 90 & & 6 & 3.50 & & 84 & \multicolumn{2}{|c|}{10.74} & 14.64 \\
\hline Mean & 75 & & 37 & 89 & & 6 & 4.11 & & .28 & \multicolumn{2}{|c|}{12.25} & 15.25 \\
\hline CD & $\mathrm{R}$ & $\mathrm{S}$ & $\mathrm{R} \times \mathrm{S}$ & $\mathrm{R}$ & $\mathrm{S}$ & $\mathrm{R} \times \mathrm{S}$ & $\mathrm{R}$ & $\mathrm{S}$ & $\mathrm{R} \times \mathrm{S}$ & $\mathrm{R}$ & $\mathrm{S}$ & $\mathrm{R} \times \mathrm{S}$ \\
\hline$(P=0.05)$ & 1.23 & 1.94 & 2.74 & 1.84 & 2.91 & 4.12 & 0.090 & 0.14 & 0.20 & 0.10 & 0.28 & 0.41 \\
\hline
\end{tabular}

Root stocks $\mathrm{R}_{1}$ : Hylocereus triangularis $\mathrm{R}_{2}$ : Myrtillocactus geometrizans

Table.3 Flowering behaviour and offshoot production ability of the inter-generic grafts

\begin{tabular}{|c|c|c|c|c|c|}
\hline \multirow[t]{2}{*}{ S. No } & \multirow[t]{2}{*}{ Combinations } & \multicolumn{2}{|c|}{$\begin{array}{l}\text { Flowering } \\
\text { behaviour }\end{array}$} & \multicolumn{2}{|c|}{ Offshoot productior } \\
\hline & & $\mathbf{R}_{1}$ & $\mathbf{R}_{2}$ & $\mathbf{R}_{1}$ & $\mathbf{R}_{2}$ \\
\hline 1. & Mammillaria beneckei $\left(\mathrm{S}_{1}\right)$ & $\mathrm{X}$ & $\checkmark$ & $\mathrm{X}$ & $\mathrm{X}$ \\
\hline 2. & Hamatocactus setispinus $\left(\mathrm{S}_{2}\right)$ & $\mathrm{X}$ & $\mathrm{X}$ & $\mathrm{X}$ & $\mathrm{X}$ \\
\hline 3. & Ferocactus latispinus $\left(\mathrm{S}_{3}\right)$ & $\mathrm{X}$ & $\mathrm{X}$ & $\mathrm{X}$ & $\mathrm{X}$ \\
\hline 4. & Echinopsis mamillosa $\left(\mathrm{S}_{4}\right)$ & $\mathrm{X}$ & $\mathrm{X}$ & $\checkmark$ & $\checkmark$ \\
\hline 5. & Gymnocalycium mihanovichii $\left(\mathrm{S}_{5}\right)$ & $\checkmark$ & $\checkmark$ & $\mathrm{X}$ & $\checkmark$ \\
\hline
\end{tabular}


Plate.1 Glass house

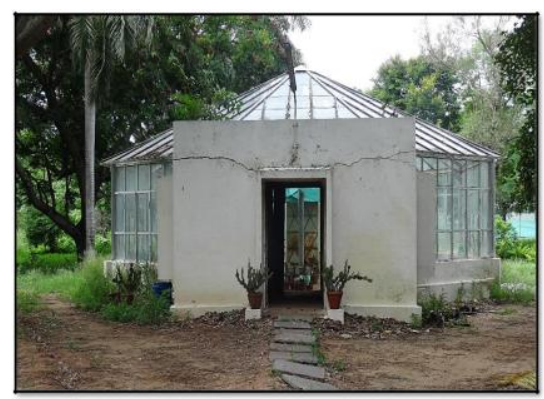

Plate.2 Field view of the experiment

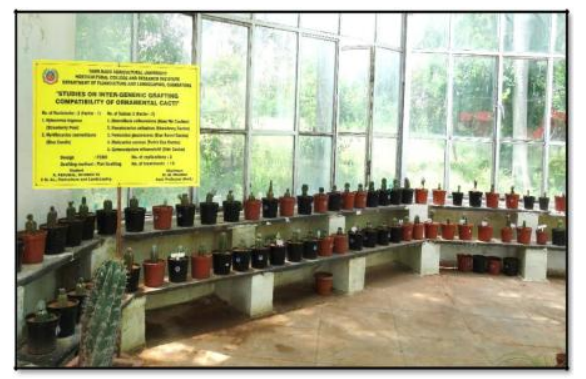

Plate.3 View of different ornamental cacti genera

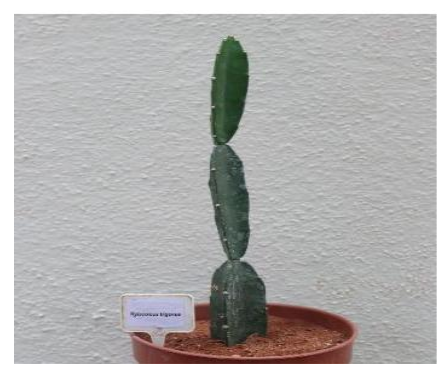

Hylocereus triangularis beneckei

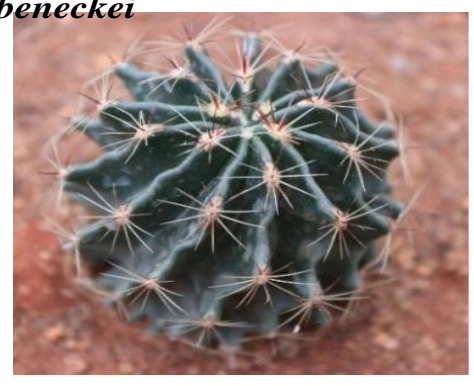

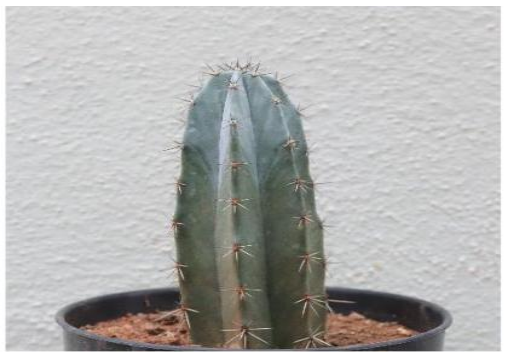

Myrtillocactus geometrizans

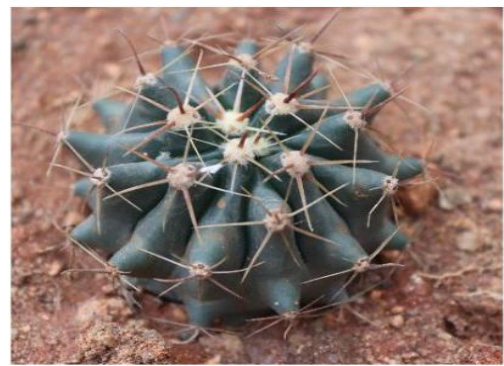

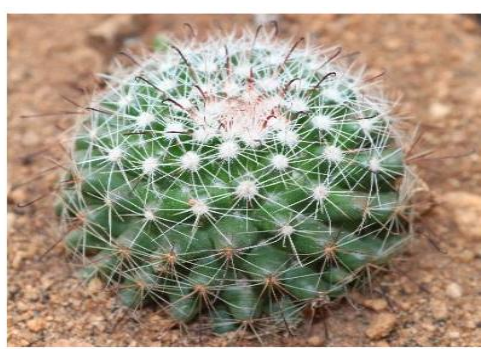

Mammillaria

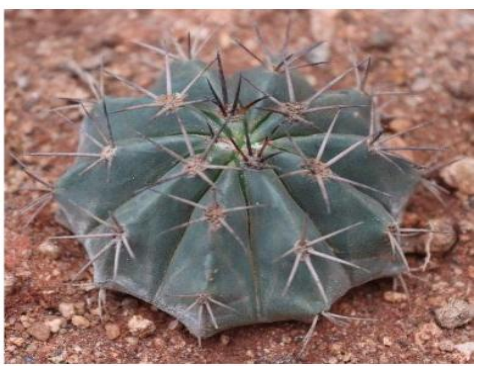

Hamatocactus setispinus caesius

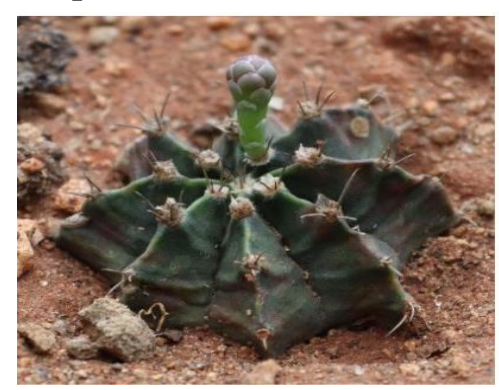

Gymnocalycium mihanovichii

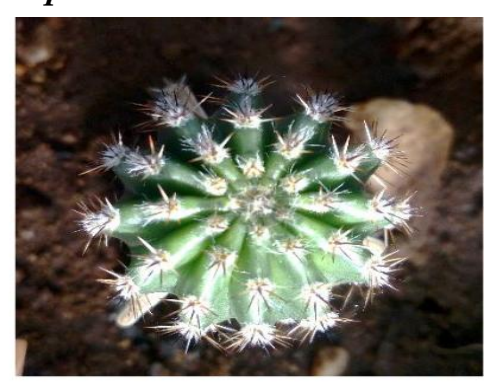

Echinopsis mamillosa 
Plate.4

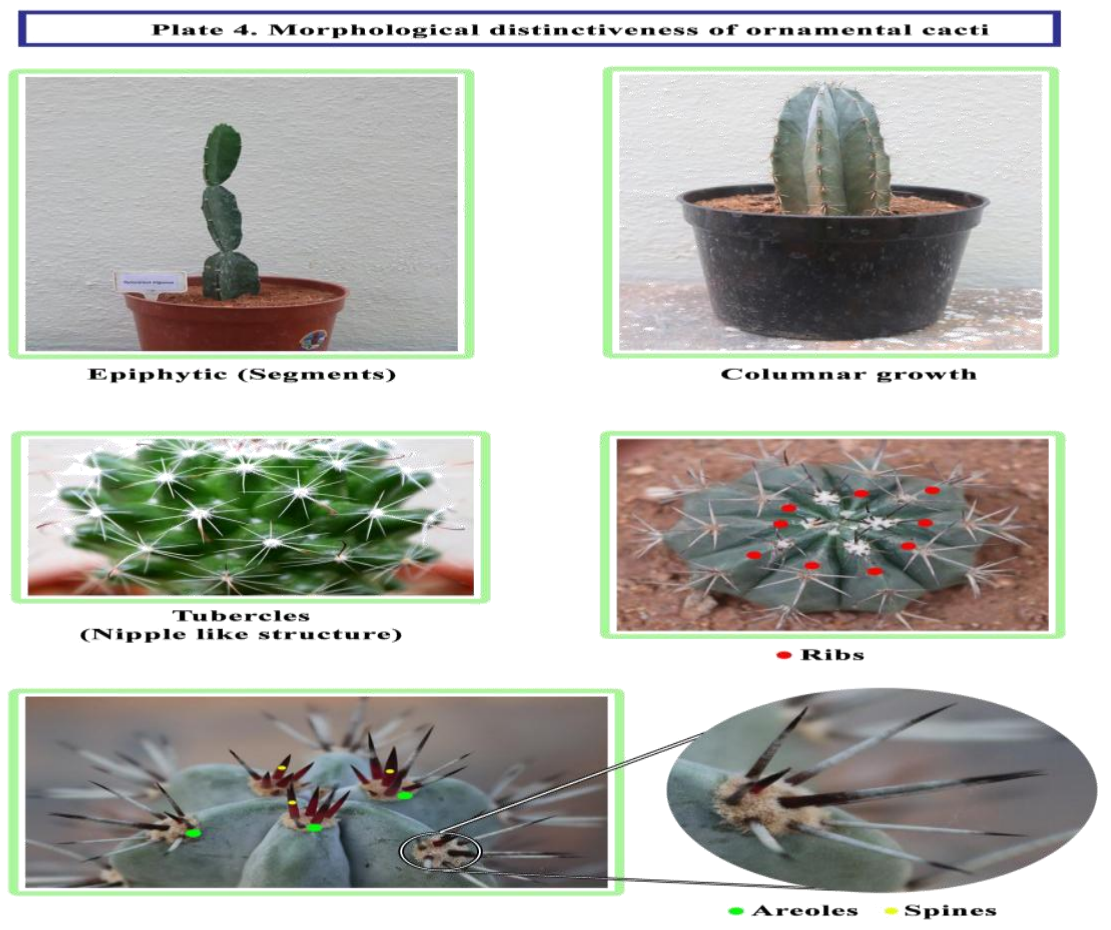

Plate.5 Internal structure of cactus
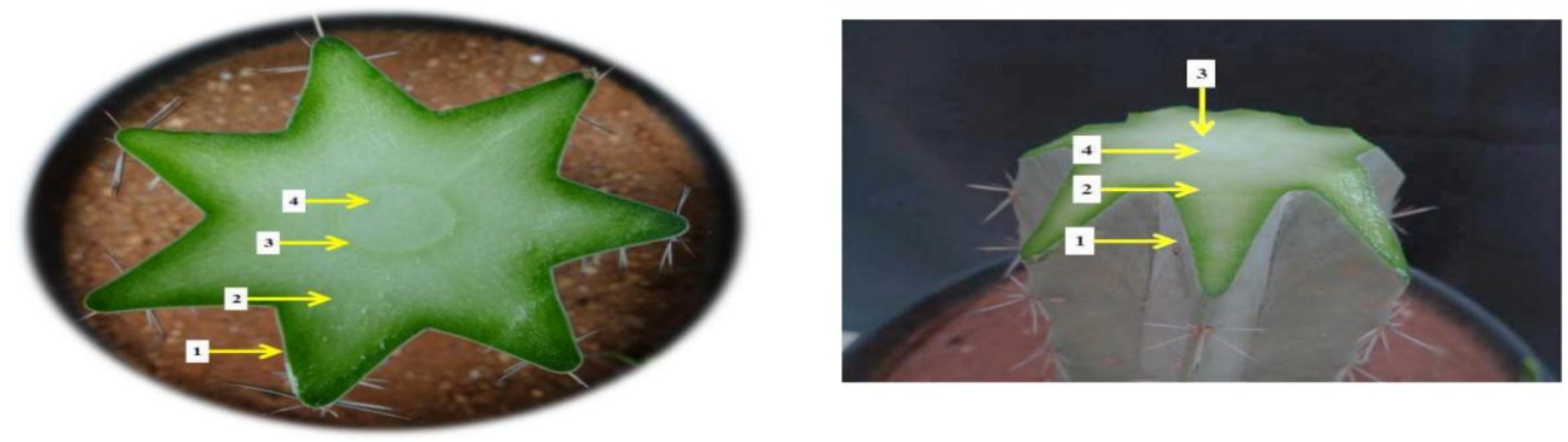

$2 \quad$ : Cortex (Largest part of flesh)

3 : Vascular bundle (A ring separating the cortex and pith)

4 : Pith (The circular center of the plant) 
Plate.6 Offshoot production and Flowering behavior on ornamental cacti

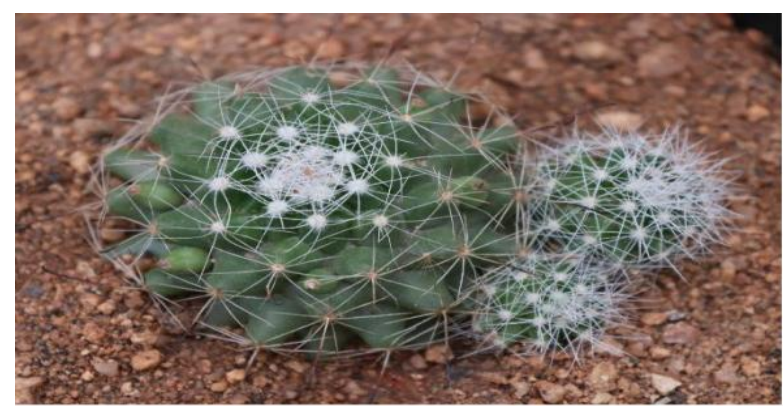

Mammillaria beneckei

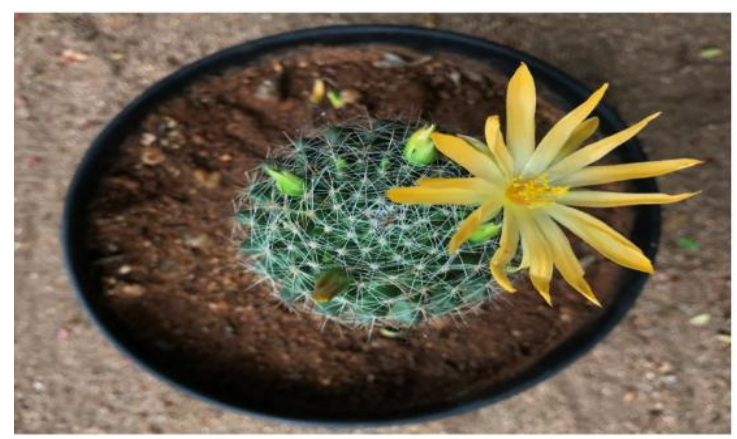

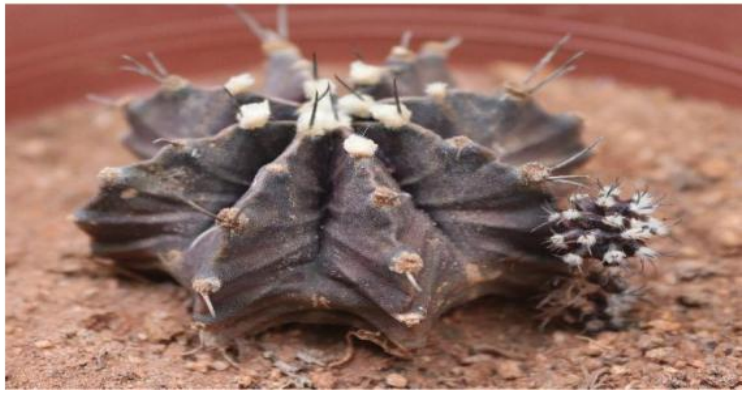

Gymnocalycium mihanovichii

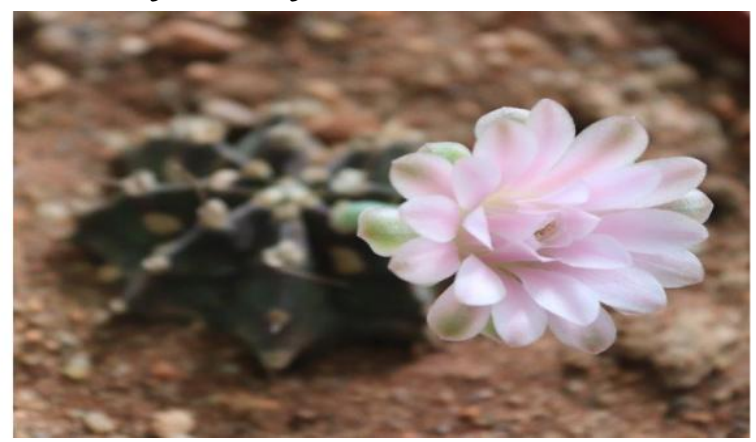

Plate. 7

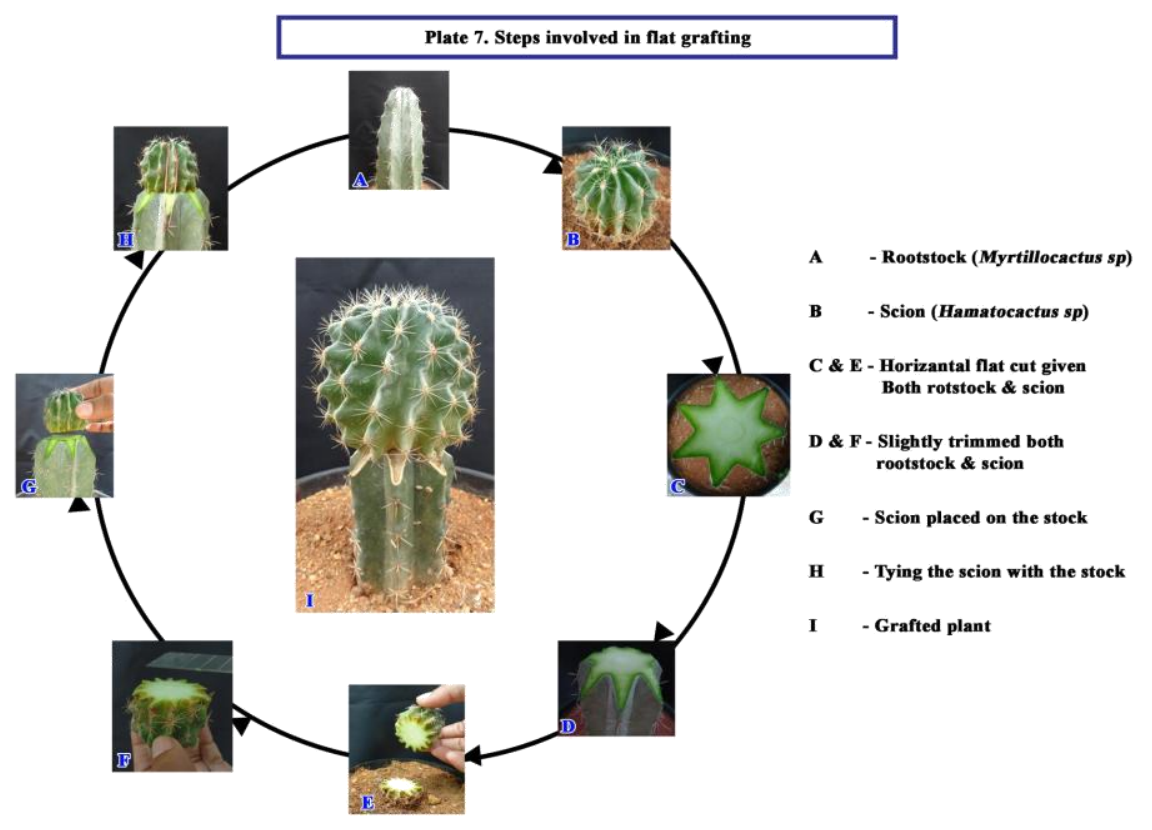




\section{Plate.8}

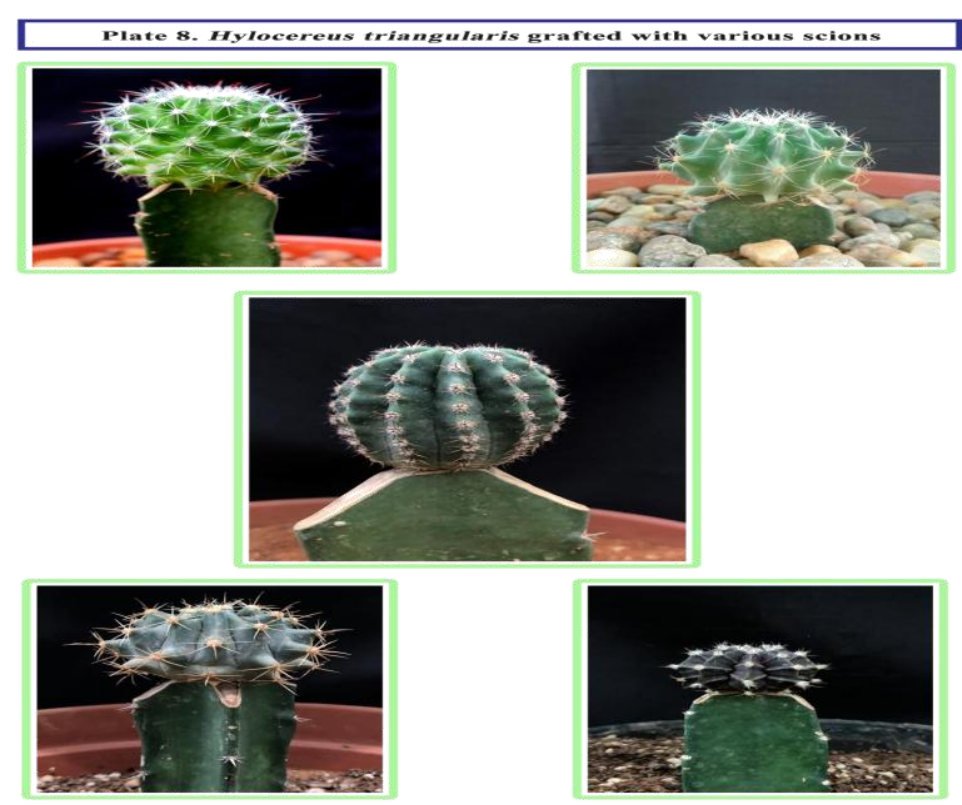

Plate.9

Plate 9. Myrtillocactus geometrizans grafted with various scions
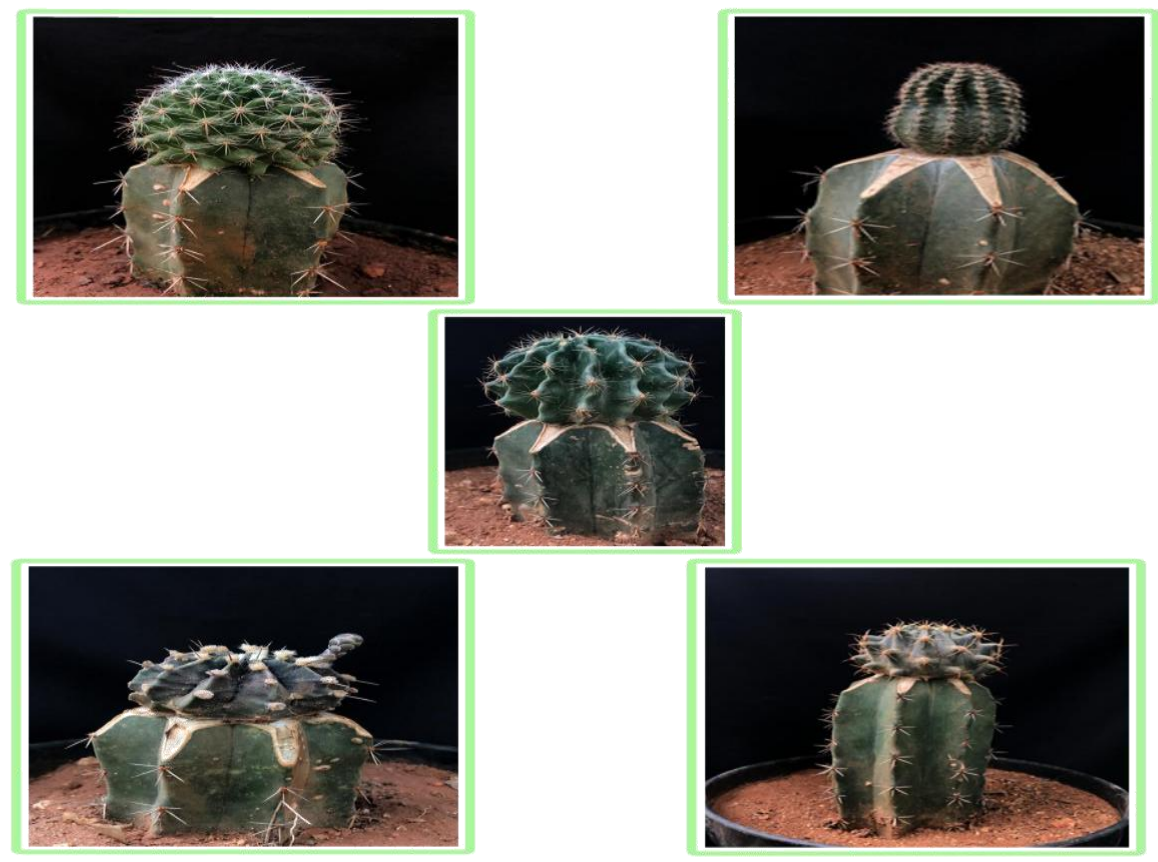
Plate.10 Offshoot production and flowering behaviour of grafted cacti
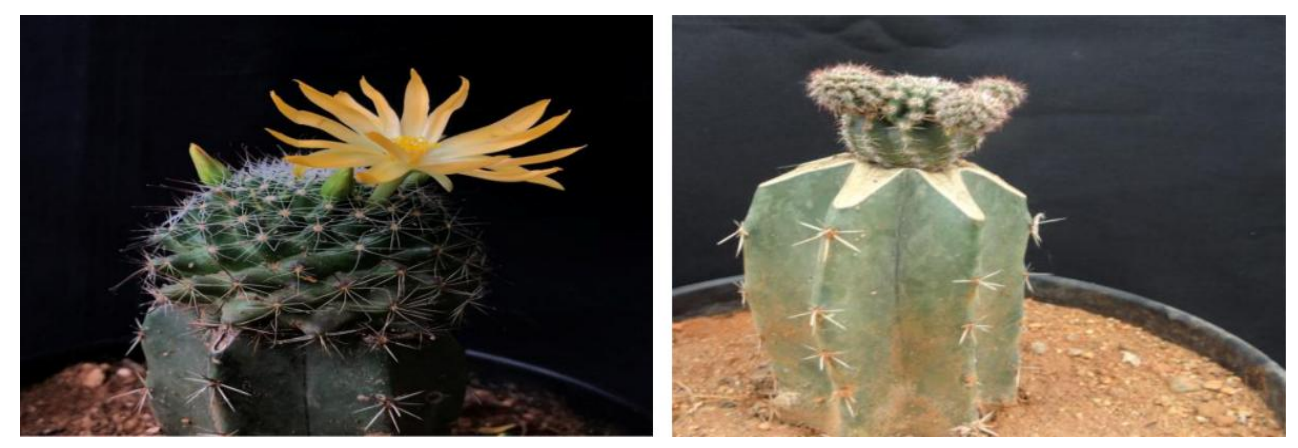

Myrtillocactus geometrizans grafted with Mammillaria beneckei

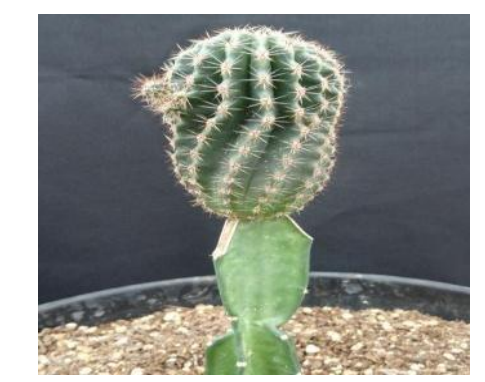

Hylocereus triangularis grafted

with Echinopsis mamillosa

Plate.11 Microtome section of inter-generic grafted cacti

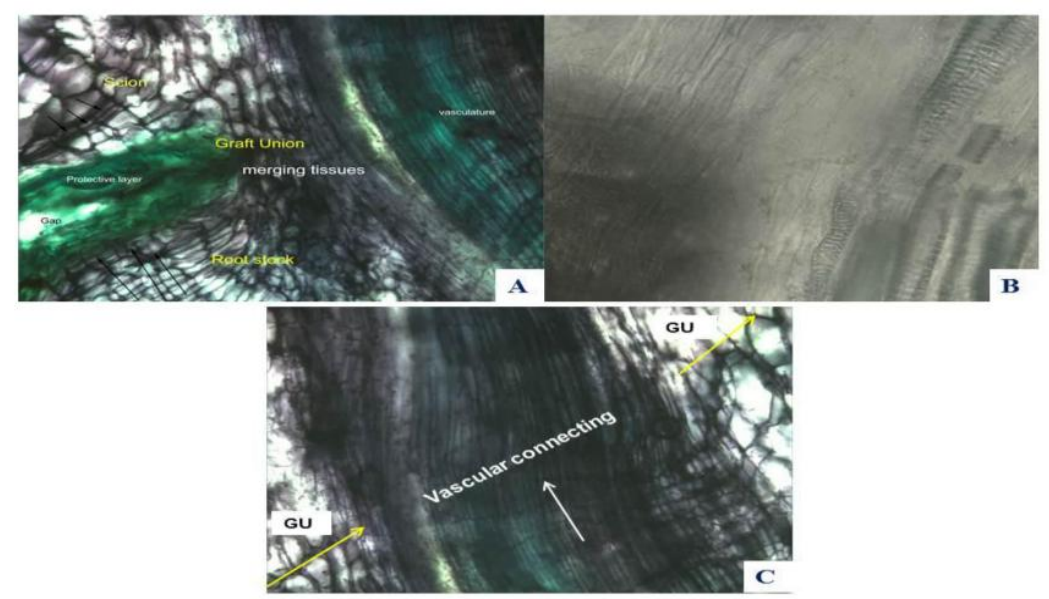

Longitudinal section of inter-generic graft between Myrtillocactus geomatrizans (Rootstock) and Gymnocalycium mihanovichii (Scion)

\begin{tabular}{|l|l|l|}
\hline A & $:$ & The graft differentiated into meristematic cells and development of vascular cambium \\
\hline B & $:$ & Graft showing elongated cells in process of differentiation to regenerate vascular tissues \\
\hline C & $:$ & Graft showing the proliferation of callus bridge cells and graft union \\
\hline
\end{tabular}


Plate.12 Growth performance of grafted ornamental cacti

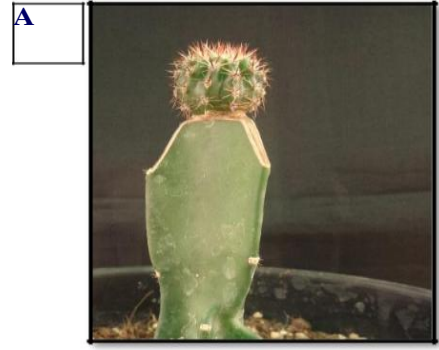

A week after grafting

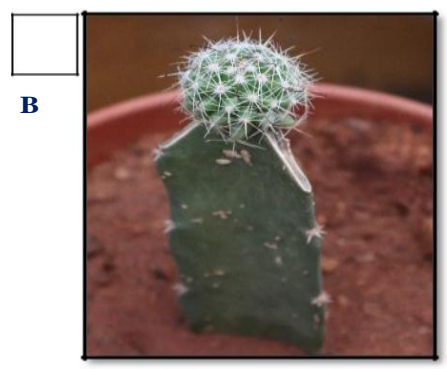

A week after grafting grafting

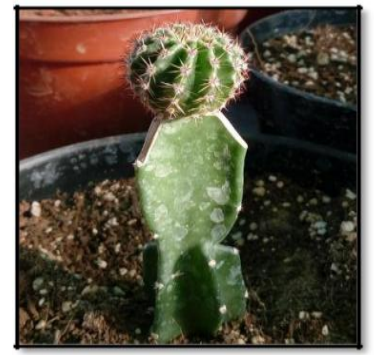

A month after grafting

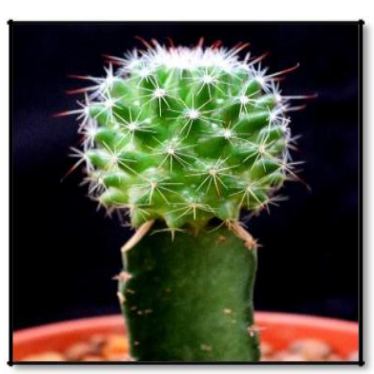

Two month after grafting Three month after

Rootstocks Hylocereus triangularis

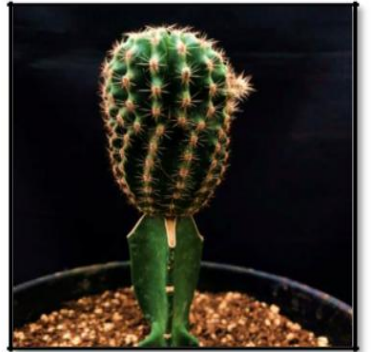

Three months after grafting

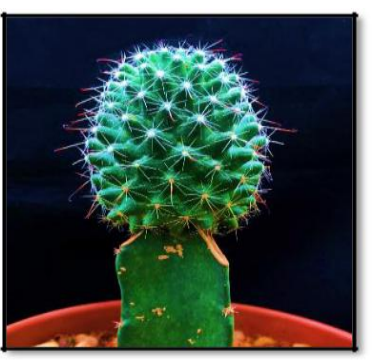

Scions

Echinopsis mamillosa Mammillaria beneckei
The results of the experiment, when grafting was done with Notocactus submammulosus var. pampeanus and rooted cuttings of Hylocereus trigonus as scions and stocks respectively, are as follows: Most of the grafts displayed have the following developmental phases: a) Cell adhesion was completed, but no cyto-differentiation was observed in the callus till the end of the experiment. b) Certain cells of callus which were oriented just under the vascular cut end of the scion differentiated into a meristematic cell nodule (Shimomura and Fuzihara, 1977).

Estrada-Luna et al., 2002 has reported that following histological observations has been revealed when Opuntia ficus-indica is grafted over $O$. streptacantha, $O$. robusta, $O$. cochinera, O. leucotricha and $O$. ficus-indica which are micro-propagated by using axillary buds as explants. They are development of necrotic layer, proliferation of Callus Bridge at the graft interface, differentiation of new vascular cambium, restoration of new vascular tissue and restoration of continuity of external epidermal tissue at the union zone and these results are found to be supporting the microtome images obtained from the inter-generic grafts.

In conclusion the intergeneric graft compatibility was found to be good when scions like Mammillaria beneckei and Echinopsis mamillosa were grafted onto Hylocereus triangularis whereas Hamatocactus setispinus and Mammillaria beneckei were found to be the suitable scions when Myrtillocactus geometrizans is used as rootstock. Reduced intergeneric graft compatibility was noticed when Ferocactus latispinus is used as scion. In future, the following aspects may be given importance to enhance 
The potentiality of cacti in the human livelihood: to analyze the release pattern of $\mathrm{CO}_{2}$ and $\mathrm{O}_{2}$ from the cacti, standardization of media and climatic requirements for different types of cacti cultivation etc.

In regard of future thrust in the field of grafting, biochemical analysis on phenolic content, enzyme assays, plant growth regulators synthesis which in turn enhances the graft success percentage.

\section{References}

Badalamenti, O., Carra, A., Oddo, E., Carimi, F. and Sajeva, M. (2016). Is in vitro micrografting a possible valid alternative to traditional micropropagation in Cactaceae Pelecyphora aselliformis as a case study? Springer Plus, 5(1), 1-4.

Bewli, C. S. (2016). Cacti culture - Prickles of Pride (First edition). New Delhi: Prakash Books India Pvt. Ltd.

Esau, K. (1965). Vascular differentiation in plants. In: Plant Anatomy, second edition. Wiley, New York.

Estrada-Luna, A. A., López-Peralta, C. and Cárdenas-Soriano, E. (2002). In vitro micro-grafting and the histology of graft union formation of selected species of prickly pear cactus (Opuntia spp.). Sci. Hort., 92(3-4), 317-327.

Johanson, D. P. (1940). Protocol for plant anatomical observations. In: Plant Micro technique. New York.: McGraw Hill Book Co. Inc.,

Motlaghzadeh, R. (2007). The World of Cacti: Raising Cacti in the Garden, Home and Apartments. Comprehensive Culture Publications.

Nei, M. (1978). Estimation of average heterozygosity and genetic distance from a small number of individuals. Genetics, 89(3), 583-590.

Perumal, R., Prabhu, M., Kannan, M. and Srinivasan, S. 2018. Morphological characterization of certain ornamental cacti genera suitable for tropical climatic regions. Journal of Agriculture and Ecology Research International, $17(1) ; 1-6$.

Shewell-Cooper, W. E. and Rochford, T. (1973). Cacti as house plants, Flowers of the Desert in your Home Blandford Press, Dorset, Great Britain.

Shimomura, T. and Fuzihara, K., 1977. Physiological study of graft union formation in Cactus. II. Role of auxin on vascular connection between stock and scion. J. Japan. Soc. Hort. Sci. 45(4): 397-406.

\section{How to cite this article:}

Perumal, R., M. Prabhu, M. Kannan and Srinivasan, S. 2020. Studies on Inter- generic Grafting Compatibility of Ornamental Cacti. Int.J.Curr.Microbiol.App.Sci. 9(11): 2133-2144. doi: https://doi.org/10.20546/ijcmas.2020.911.253 